\title{
Effect of Propolis Extract on Biodistribution of Sodium Pertechnetate $\left(\mathrm{Na}^{99 \mathrm{~m}} \mathrm{TcO}_{4}\right)$
}

Cecília Maria de Carvalho Xavier Holanda, MD, PhD; Vanessa Santos de Arruda Barbosa, MD, PhD; Yullyanna Moreira Rodrigues; Eider Maia Saraiva; Vanessa Fávero Demeda; Hilkéa Carla Sousa de Medeiros, MD; Maria Kadja Meneses Torres Açucena, MD; Tarciso Bruno Montenegro Sampaio; Aldo da Cunha Medeiros, MD, $\mathrm{PhD}$.

\footnotetext{
Research performed at Antiparasitic Assays Laboratory, Department of Microbiology and Parasitology, Federal University of Rio Grande do Norte (UFRN), Brazil.

Financial support: none

Conflict of interest: none

Correspondence address: Cecília Maria de Carvalho Xavier Holanda, Department of Microbiology and Parasitology, Federal University of Rio Grande do Norte (UFRN), Brazil, at Ave. Sen. Salgado Filho, 3000, Natal, RN, Brazil, Email: cechol@ufrnet.br

Submitted: 01 November 2013. Accepted, after review: 18 December 2013.
}

\begin{abstract}
Objective: Propolis is a bee product useful natural substance applied in medicine. We have investigated the effect of propolis extract on biodistribution of sodium pertechnetate $\left(\mathrm{Na}^{99 \mathrm{~m}} \mathrm{TcO}_{4}\right)$ and laboratorial parameters in rats. Methods: It was administered, by gavage, $1.0 \mathrm{ml} /$ day of propolis into 10 rats (treated group) during 10 days and $1.0 \mathrm{ml} /$ day of saline solution into other 10 rats (control group), by the same via and period. On the $10^{\text {th }}$ day, after $60 \mathrm{~min}$, all the animals received $0.1 \mathrm{ml}$ of $\mathrm{Na}^{99 \mathrm{~m}} \mathrm{TcO}_{4}$ by ocular via. $50 \%$ of each group of rats was killed after $10 \mathrm{~min}$ and other $50 \%$, after $30 \mathrm{~min}$. Samples of brain, stomach, small bowel, liver, kidneys, thyroid and lungs were isolated and the \%ATI/g of each organ was calculated. Tissue samples were taken from all the organs and stained by HE and PAS. Data were compared by Mann-Whitney and Student's t-tests $(p<0.05)$. Results: There was a statistically significant increase in the \%ATI/g, from control to treated group, respectively, in small bowel $(0.15 \pm 0.01$ to $0.32 \pm 0.09$, after $10 \mathrm{~min}$ and $0.32 \pm 0.03$ to $0.42 \pm 0.02$, after $30 \mathrm{~min})$ and blood $(0.22 \pm 0.01$ to $0.48 \pm 0.02$, after $10 \mathrm{~min}$ and $0.38 \pm 0.02$ to $0.51 \pm 0.04$, after 30min).Conclusion: Propolis extract facilitated the uptake of $\mathrm{Na}^{99 m} \mathrm{TcO}_{4}$ in some organs of rats and increased levels of some laboratorial parameters.
\end{abstract}

Keywords: Propolis. Herbal Medicine. Sodium Pertechnetate Tc 99m. Radiopharmaceuticals. Rats

\section{INTRODUCTION}

Propolis (bee glue) is the generic name given to resinous substances collected by honeybees from various plant sources. Propolis has attracted much attention in 
recent years as a useful natural substance applied in medicine, even it is known in folk medicine since ancient times. This natural substance contains more than 300 components, including phenolic aldehydes, polyphenols, sequiterpene quinines, coumarins, steroids, aminoacids and inorganic compounds ${ }^{1}$. Interest in propolis as harmless medicine has increased because of its broad spectrum of biological properties, such as: antibacterial, analgesic, anti-inflammatory, antioxidant and immunoenhancement, antiproliferative activity in human tumor cells, antitumor activity in mice and radioprotective effects in in vitro cultures ${ }^{2,3,4}$.

lonizing radiation in interaction with living cells causes a variety of changes depending on exposed and absorbed dose, duration of exposure and interval after exposure and susceptibility of tissues ${ }^{5}$. Efforts to reduce toxicity to normal tissue cells and organs have led into searching for cytoprotective agents. Unfortunately, most of chemical radioprotectors have toxic side effects, which limit their use in medical practice. Investigations for effective and nontoxic compounds with radioprotection capability led to increasing interest in naturally occurring antioxidant such as propolis and its polyphenolic compounds ${ }^{5}$.

Technetium-99m ( $\left.{ }^{99 m} \mathrm{Tc}\right)$ is an artificial radionuclide obtained in the form of sodium pertechnetate $\left(\mathrm{Na}^{99 \mathrm{~m}} \mathrm{TcO}_{4}\right)$ directly from the generator of ${ }^{99} \mathrm{Mo} /{ }^{99 \mathrm{~m}} \mathrm{Tc}$ on elution with physiologic saline $(0.9 \% \mathrm{NaCl})$. The vital role of ${ }^{99 \mathrm{~m}} \mathrm{Tc}$ in the field of diagnostic nuclear medicine is well established. The evolution of diagnostic nuclear medicine can be principally attributed to the existence and chemical versatility of ${ }^{99 m} \mathrm{Tc}$, the ideal radiotracer, which is used predominantly in one form or another in nuclear medicine ${ }^{6}$. Rapid growth in this field in the last few decades is attributable, apart from its ideal radionuclidic characteristics, to the conception and development of generators and lyophilized kits for ease of formulation of ${ }^{99 \mathrm{~m}} \mathrm{Tc}$ compounds in hospital radiopharmacies ${ }^{6}$.

Factors, such as synthetic drugs as glucantime ${ }^{7}$, mefloquine ${ }^{8}$, paclitaxel ${ }^{9}$, rochagan $^{10}$, morphine ${ }^{11}$, tamoxifen ${ }^{12}$ or natural drugs such as artemisinin ${ }^{8}$, Punica granatum $^{13}$, Aloe vera ${ }^{14}$ and dietary conditions could affect the biodistribution of radiopharmaceuticals ${ }^{8,14}$.

The radiopharmaceutical sodium pertechnetate is uptaken by stomach, intestinal tract, thyroid and salivary glands and several natural or synthetic drugs can change the biological effect of the radiopharmaceutical and their interaction can lead to hypo or hyper uptake of radiopharmaceuticals in a particular organ, causing incorrect diagnosis or misinterpretation of results ${ }^{15}$. In addition, repeated scintigraphic may result in unnecessary radiation for patients ${ }^{15}$. Although the propolis extract is widely used and useful natural substance applied in folk medicine, no data about diary consumption of this product on biodistribution of radiopharmaceuticals or effects upon the histopathology and laboratorial parameters in rats have been described. Thus, the aim of this work was to evaluate the chronic effect of the propolis extract on 
histology, biochemical and hematological parameters and on the uptake of sodium pertechnetate in organs of Wistar rats.

\section{METHODS}

\section{ANIMALS}

Wistar rats (2-3 months, 150-250g) were housed in an environmentallycontrolled room $\left(23 \pm 2^{\circ} \mathrm{C}\right)$, with free access to water and food. Experimental procedures were conducted in accordance with the Ethical Committee of Animal Use of the Centro de Biociências, Universidade Federal do Rio Grande do Norte (protocol number CEUA 027/2011).

\section{PROPOLIS EXTRACT}

The propolis extract (prepared from a 10\% dye-mother solution and diluted in saline solution, Herbarium Laboratory, Rio de Janeiro/Brazil) was administered orally $(1.0 \mathrm{~mL} /$ day) into male Wistar rats $(\mathrm{n}=10)$, in single dose during 10 days (treated group). The control group $(n=10)$ received $1.0 \mathrm{~mL} /$ day of saline solution by the same way and period.

\section{BIODISTRIBUTION OF SODIUM PERTECHNETATE}

Sixty minutes after the last dose of propolis extract or saline solution (on the $10^{\text {th }}$ day of the treatments) all the animals were injected with $0.1 \mathrm{~mL}$ of the $\mathrm{Na}^{99 \mathrm{~m}} \mathrm{TcO}_{4}$ $(0.66 \mathrm{MBq})$, via orbital plexus. The sodium pertechnetate was eluted from a ${ }^{99} \mathrm{Mo} /{ }^{99 \mathrm{~m}} \mathrm{Tc}$ generator produced by the Institute of Energy and Nuclear Research, São Paulo/Brazil. After this, $50 \%$ of each group of animals were quickly killed by anesthetic overdose (thiopental sodium $50 \mathrm{mg} / \mathrm{kg}$, intraperitoneally) after $10 \mathrm{~min}$, and $50 \%$, after $30 \mathrm{~min}$. Blood and organ samples (brain, stomach, small bowel, colon, liver, kidneys, thyroid and lungs) were isolated, cleaned with $0.9 \%$ saline solution and the radioactivity of each organ was determined by means of an automatic gamma counter (1470 Wizard, Perkin Elmer, Finland) with automatic correction for decay and efficiency of $86 \%$. The percentage of radioactivity per gram of each tissue or organ $(\% \mathrm{ATI} / \mathrm{g})$ was calculated as described elsewhere Bernardo-Filho et al. $(2005)^{15}$.

\section{HISTOLOGICAL EXAMINATION}

Frozen tissue samples were taken from all the organs studied. The specimens were fixed in $10 \%$ formalin, cut as $5 \mu \mathrm{m}$ tissue sections and stained with Hematoxylin-Eosin (HE) and Periodic Acid-Schiff (PAS). All specimens were 
examined by the same pathologist, who had no knowledge of the study groups. Morphometric measurements were made using light micrographs $(100 \mathrm{X})$ of the stained sections.

\section{LABORATORIAL PARAMETERS}

Hematological blood parameters were measured by an Abbot CellDyn 3500R autoanalyzer. The biochemical levels were measured using the Konelab 60i spectrophotometer, (assay kit from Weiner, São Paulo, Brazil). All data were presented as mean \pm standard deviation.

\section{STATISTICAL ANALYSIS}

Data is reported as means $\pm \mathrm{SD}$. The \%ATl/g and histological analysis were compared by Mann-Whitney test and hematological analysis and biochemical parameters were compared by the Student's $t$-test, considering $p<0.05$ statistically significant in both tests. In Stat Graph Pad software was used to perform statistical analysis.

\section{RESULTS}

The Table 1 shows the biodistribution of $\mathrm{Na}^{99 \mathrm{~m}} \mathrm{TcO}_{4}$ in organs of control group rats and treated group rats. There was a statistically significant increase $(p<0.05)$ in the uptake of ${ }^{99 \mathrm{~m}} \mathrm{TcO}_{4}{ }^{-}$in the small bowel and blood in both period (after 10 and 30 $\mathrm{min}$ ) of treated animals, when compared with controls. The ${ }^{99 \mathrm{~m}} \mathrm{TcO}_{4}{ }^{-}$had no altered biodistribution in the other organs studied in both periods.

Table 1 Effect of propolis extract on the uptake of $\mathrm{Na}^{99 \mathrm{~m}} \mathrm{TcO}_{4}$ in blood and small bowel of rats.

\begin{tabular}{lcccc}
\hline \multirow{2}{*}{ Organs } & \multirow{2}{*}{ Period $(\mathrm{min})$} & \multicolumn{2}{c}{$\%$ ATI/g } & \multirow{2}{*}{ p-value } \\
\cline { 3 - 4 } & & Control group & Treated group & \\
\hline Blood & 10 & $0.22 \pm 0.01$ & $0.48 \pm 0.02$ & $0.0285^{\star}$ \\
Blood & 30 & $0.38 \pm 0.02$ & $0.51 \pm 0.04$ & $0.0485^{\star}$ \\
Small bowel & 10 & $0.15 \pm 0.01$ & $0.32 \pm 0.09$ & $0.0208^{\star}$ \\
Small bowel & 30 & $0.32 \pm 0.03$ & $0.42 \pm 0.02$ & $0.0305^{\star}$ \\
\hline
\end{tabular}

Data are reported as means $\pm S D .{ }^{\star} p<0.05$, compared with control. 
The Table 2 shows a significant increase in the seric levels of glucose, albumin, alkaline phosphatase and alanine aminetransferase in the treated rats, compared with controls. Histological analysis of the organs by HE and PAS of both groups showed no histopathological alterations. There was no alteration on hematological blood parameters of the treated group when compared with control group (data no showed).

Table 2 - Effect of propolis extract in some biochemical parameters of rats.

\begin{tabular}{lccc}
\hline \multicolumn{1}{c}{ Parameters } & Control group & Treated group & p-value \\
\hline Albumin $(\mathrm{mg} / \mathrm{dL})$ & $2.27 \pm 0.17$ & $3.77 \pm 0.15$ & $0.0418^{*}$ \\
Alkaline phosphatase $(\mathrm{UI} / \mathrm{L})$ & $156.01 \pm 6.14$ & $189.20 \pm 7.12$ & $0.0250^{*}$ \\
Alanine aminetransferase $(\mathrm{UI} / \mathrm{L})$ & $40.90 \pm 3.30$ & $56.70 \pm 3.91$ & $0.0241^{*}$ \\
Glucose $(\mathrm{mg} / \mathrm{dL})$ & $96.60 \pm 6.59$ & $111.40 \pm 7.30$ & $0.0312^{*}$ \\
\hline
\end{tabular}

Data are reported as means $\pm S D .{ }^{*} p<0.05$, compared with control.

\section{DISCUSSION}

Propolis is a bee product, made from plant exudates, used for the construction and repair of the hive, as well as protection against microorganisms. It is a complex mixture, with more than 300 compounds already identified in different samples ${ }^{1}$. Cumulative evidence suggests that propolis may have anti-inflammatory, antibiotic, antioxidant, antihepatotoxic, and antitumor properties. Such effects have been associated with the presence of phenolic compounds, such as flavonoids and aromatic acids ${ }^{2}$. In addition, to topical applications, products containing propolis have been used increasingly as dietary supplements. Although reports of allergic reactions are not uncommon, propolis is reputed to be relatively nontoxic. Its systemic toxicity is rarely reported and hence may be underestimated ${ }^{16}$. Since propolis extract has been widely used in traditional phytomedicine and no data about diary consumption of this product on biodistribution of radiopharmaceuticals or effects upon the histopathology and the laboratorial parameters in rats have been described, it was the main reason for its use in this study.

The composition of propolis depends on time, vegetation, and the collection area. Considerable variation exists in the chemical composition of propolis, even within such a country as Brazil ${ }^{16}$. Chemical analysis of propolis extracts indicated that propolis samples had high concentrations of aromatic acids, esters and other derivatives, such as benzyl cinnamate, methyl cinnamate, caffeic acid, cinnamyl cinnamate and cinnamoylglcine, so the composition of propolis is extremely complex. In patients with suspected drug induced organ damage, propolis often is regarded as a natural compound and an innocent bystander. Hence, the cause of systemic toxicity usually is unknown and rarely attributed to propolis ${ }^{16}$. 
Yi-Jung et al. (2005) ${ }^{17}$ studied the first case report of propolis-induced acute renal failure. This case indicated that propolis can induce acute renal failure and emphasizes the need for vigilance and care when propolis is used as a medicine or dietary supplement. Moreover, it is very difficult to identify definitely the compound causing acute renal failure. Furthermore, contamination by other toxic agents in the process of extracting, manufacturing and storing propolis is another potential factor in propolis-induced acute renal failure ${ }^{1,17}$. As an herbal remedy, propolis is used commonly and reputed for its therapeutic properties and relatively few systemic adverse effects ${ }^{1}$.

Scintigraphic techniques allow the measurement of physiological processes, as well as the determination of alterations related to various diseases. In general, a radiopharmaceutical used in scintigraphic techniques presents a normal biodistribution that might be altered due to diseases and many others factors, such as drugs or natural products ${ }^{6,14}$. This fact helps the physicians to define the diagnosis about a disease with the analysis of scintigraphic images ${ }^{15}$.

Although the propolis extract is widely used and useful natural substance applied in folk medicine, no data about diary consumption of this product on the biodistribution of radiopharmaceuticals or effects upon the histology and biochemical parameters in rats have been described. However, others natural products also abundantly used in folk medicine were already studied being evaluated those aspects. For example, Holanda et al. (2009) ${ }^{14}$ showed that the aqueous extract of Aloe vera increased the uptake of the sodium pertechnetate in femur, kidneys, liver, stomach, testis and thyroid of organs of Wistar rats and decreased the levels of some biochemical parameters. Santos-Filho et al. $(2005)^{18}$ demonstrated that Hypericum perforatum reduced significantly the radioactivity percentage in bone, muscle and thyroid and increased in the pancreas of animals. Moreno et al. (2004) ${ }^{19}$ showed that Ginkgo biloba also altered the uptake of the radiopharmaceuticals in kidneys, liver and duodenum of rats and Braga et al. (2012) ${ }^{6}$ showed that the aqueous carqueja extract decreased the radiolabeling of blood constituents with technetium-99m $\left({ }^{99 \mathrm{~m}} \mathrm{Tc}\right)$.

The present study showed that propolis extract increased the uptake of the sodium pertechnetate in blood and small bowel of Wistar rats after 10 and 30 min of the injection of $\mathrm{Na}^{99 \mathrm{~m}} \mathrm{TcO}_{4}$. This fact indicate that the propolis extract facilitated the uptake of the $\mathrm{Na}^{99 \mathrm{~m}} \mathrm{TcO}_{4}$ in organism of Wistar rats treated with this natural drug and, probably, it not interfere in scintigraphic examinations of patients in use of this natural product. There was also increase in seric levels of glucose, albumin, alkaline phosphatase (AP) and alanine aminetransferase (ALT) in the treated rats, compared with controls. The increase of levels of serum AP, ALT and albumin can indicate deterioration in the functions of the liver and cellular hepatic damage. Unfortunately, hepatic toxicity is a potential complication of natural compounds that may lead to hepatic insufficiency ${ }^{20}$. The alterations on hepatic enzymes (ALT and AP) in this 
study, probably, occurred due to the alcohols, esters and aldehydes present in the studied concentration of propolis extract capable to damage hepatic cells ${ }^{20}$.

\section{CONCLUSION}

In conclusion, the results of this study indicate that the propolis extract was responsible for the increased levels of liver enzymes alkaline phosphatase and alanine aminetransferase, demonstrating a small toxic effect on the liver, and it does not prevent uptake of the radiopharmaceutical $\mathrm{Na}^{99 \mathrm{~m}} \mathrm{TcO}_{4}$ in the small bowel and blood of experimental animals.

\section{REFERENCES}

1. Khali ML. Biological activity of bee propolis in health and disease. Asian Pac J Cancer Prev. 2006;7: 22-31.

2. Orsolic N, Saranovic AB, Basic I. Direct and indirect mechanism(s) of antitumour activity of propolis and its polyphenolic compounds. Planta Med. 2006;72: 20-7.

3. Chen $\mathrm{Ch}$, Weng $\mathrm{M}, \mathrm{Wu} \mathrm{Ch}$, Lin J. Comparision of radical scavenging activity, cytotoxic effects and apoptosis induction in human melanoma cells by Taiwanese propolis from different sources. Compl Altern Med. 2004; 1:175-85

4. Montoro A, Almonacid M, Serrano J, Saiz M, Barquinero JF, Barrios L. Assessment by cytogenetic analysis of the radioprotection properties of propolis extract. Radiat Prot Dosim. 2004;115(1-4): 461-4.

5. Sankaranarayanan K. Estimation of the genetic risks of exposure to ionizing radiation in humans: current status and emerging perspectives. J Radiat Res. 2006; 47:57-66.

6. Braga AC, Gomes ML, Santos J, Fernandes JF, Frederico EF, Pereira MO, Bernardo-Filho M. Alteration of the labeling of blood constituents with technetium$99 \mathrm{~m}$ and the morphology of red blood cells by Baccharis trimera extract. Afr $\mathrm{J}$ Pharm Pharmacol. 2012; 6: 228-34.

7. Holanda CMCX, Leite RCH, Catanho MTJA, Souza GML, Bernardo-Filho, M. The effect of glucantime ${ }^{T M}$ on the labeling of blood constituents with technetium99m. Acta Cir Bras. 2005; 20 (1): 126-30.

8. Holanda CMCX, Leite RCH, Nunes RAS, Oliveira HA, Catanho MTJA, Souza GML, Bernardo-Filho M. Effect of antimalarial drugs on the bioavailability of the methylene diphosphonic acid labeled with technetium-99m in Wistar rats. Braz Arch Biol Technol. 2006; 49:207-14.

9. Holanda CMCX, Oliveira EH, Rocha LG, Barbosa VSA, Spyrides MHC, Aragão CFS, Bernardo-Filho M Medeiros, AC. Effect of paclitaxel (Taxol) on the biodistribution of sodium pertechnetate $\left(\mathrm{Na}^{99 \mathrm{~m}} \mathrm{TcO}_{4}\right)$ in female Wistar rats. Braz Arch Biol Technol. 2008;51:191-6. 
10. Barbosa VSA, Xavier-Holanda CMC, Silva RP, Oliveira DP, Silva-Júnior MF, Oliveira EH, Bernardo-Filho M. Effect of tripanosomicide benznidazole (Rochagan) on the biodistribution of sodium pertechnetate $\left(\mathrm{Na}^{99 \mathrm{~m}} \mathrm{TcO}_{4}\right)$ in Wistar rats. Braz Arch Biol Technol. 2008; 51: 175-80

11. Jales-Jr LH, Xavier Holanda CMC, Ramos AMO, Jales RLC, Amorim, LF, Bernardo-Filho M. Influence of the morphine on the kinetic of biodistribution of Technetium-99m labeled with MDP in Wistar rats. J Animal Veter Adv. 2004;3 (5):306-10.

12. Britto LML, Xavier-Holanda CMC, Jales RLC, Marques FMH, Jales-Jr LH, Brandão KC, Bernardo-Filho M. Effects of tamoxifen on the kinetic of biodistribution of radiopharmaceuticals in Wistar rats. J. Animal Veter. Adv. 2004; 3 (4): 208-12.

13. Amorim LF, Xavier-Holanda CMC, Catanho MT, Terra DA, Brandão KC, Jales-Jr LH, Britto LML, Gomes ML, Melo VG, Bernardo-Filho M, Jales RLC. Assessment of the effect of Punica granatum (pomegranata) on the bioavailability of the radiopharmaceutical sodium pertechnetate $\left({ }^{99 \mathrm{~m}} \mathrm{Tc}\right)$ in Wistar rats. Cell Mol Biol. 2003; 49 (4): 501-7.

14. Holanda CMCX, Costa MB, Silva NCZ, Silva-Junior MF, Barbosa VSA, Silva RP, Medeiros AC. Effect of an extract of Aloe vera on the biodistribution of sodium pertechnetate $\left(\mathrm{Na}^{99 \mathrm{~m}} \mathrm{TcO}_{4}\right)$ in rats. Acta Cir Bras. 2009; 24 (5): 383-6.

15. Bernardo-Filho M, Santos-Filho SD, Moura EG, Maiworm Al, Orlando MMC, Penas ME, Cardoso VN, Bernardo LC, Brito LC. Drug interaction with radiopharmaceuticals: a review. Braz Arch Biol Technol. 2005; 48:13-27.

16. Sahinler N, Kaftanoglu O. Natural product propolis: Chemical composition. Nat. Prod. Res. 2005; 19:183-8.

17. Yi-Jung Li, Ja-Liang Lin, Chih-Wei Yang, Chun-Chen Yu. Acute renal failure induced by a Brazilian variety of propolis. Am J Kidney Dis. 2005; 46:125-9.

18. Santos-Filho SD and Bernardo-Filho M. Effect of Hypericum perforatum extract on in vitro labeling of blood elements with technetium-99m and on biodisponibility of sodium pertechnetate in Wistar rats. Acta Cir Bras. 2005;20 (1):121-5.

19. Moreno SRF, Carvalho JJ, Nascimento ALR, Bernardo-Filho M. Bioavailability of sodium pertechnetate and light microscopy of organs isolated from the rats: study of the effects of a Ginkgo biloba extract. Pakistan J. Nutr. 2004;1:64-7.

20. Pittler MH, Ernest E. Systematic review: hepatotoxic events associated with herbal products. Alim Pharmacol Ther. 2003;18:451-71. 